\title{
GAMBARAN KUALITAS HIDUP LANSIA YANG TINGGAL DI PANTI SOSIAL TRESNA WREDA X JAKARTA
}

\author{
Hanna Hadipranoto ${ }^{1}$, Heryanti Satyadi ${ }^{2}$, Rostiana $^{3}$ \\ ${ }^{1}$ Prodi Magister Psikologi Profesi, Universitas Tarumanagara, Jakarta \\ Email: hanna.717172004@stu.untar.ac.id \\ ${ }^{2}$ Fakultas Psikologi, Universitas Tarumanagara, Jakarta \\ Email: heryanti.satyadi@gmail.com \\ ${ }^{3}$ Fakultas Psikologi, Universitas Tarumanagara, Jakarta \\ Email: rostiana@fpsi.untar.ac.id
}

Masuk : 17-03-2020, revisi: 28-04-2020, diterima untuk diterbitkan : 30-04-2020

\begin{abstract}
Elderly residential home can be a safe place for elderly because of their limitations, even though some of them feel unappreciated and finally they feel more alienated and helplessness. They also feel limited in doing activities related to family or friends. This perception of the elderly can affect their quality of life. Quality of life is someone's perception about their life experiences related with their goals and expectations. This study discusses the quality of life of the elderly who live in the government residential home. This research is a descriptive study using Quality of Life for the Elderly questionnaire that has been adapted with Indonesian culture. Sampling was conducted using purposive sampling technique. Participats in this study were 30 young older people age 60-74 years. The results showed that $6(20 \%)$ participants had low quality of life, $16(53.3 \%)$ participants had moderate quality of life and 8 (26.7\%) participants had high quality of life. Participants have most satisfied perceptions on the domain of independence $(4,1778)$, spirituality $(3,8667)$ and physical health $(3,667)$. The t-test indicate that quality of life is different only based on the length of time they lived in the institution
\end{abstract}

Keywords: quality of life, elderly, residential home.

\begin{abstract}
ABSTRAK
Panti wreda dapat menjadi tempat tinggal yang aman bagi lansia karena ketidakberdayaan mereka, namun beberapa lansia yang tinggal di panti wreda merasa kurang dihargai dan diberdayakan sehingga timbul perasaan terasing dan semakin tidak berdaya. Mereka juga merasa terbatas dalam melakukan kegiatan serta kontak dengan keluarga atau teman-teman. Persepsi lansia ini dapat mempengaruhi kualitas hidupnya. Kualitas hidup (quality of life) merupakan persepsi dari pengalaman individu itu sendiri tentang kehidupannya yang disesuaikan dengan budaya serta sistem nilai di lingkungan terkait dengan tujuan, harapan, standar, serta masalah yang dihadapinya. Penelitian ini bertujuan untuk menggambarkan kualitas hidup lansia yang tinggal di panti sosial tresna wreda. Penelitian ini merupakan penelitian deskriptif menggunakan alat ukur Kualitas Kehidupan Lansia yang telah diadaptasi sesuai budaya Indonesia oleh Dewi, Rostiana \& Rumawas (2018). Pengambilan sampel dilakukan dengan menggunakan purposive sampling. Partisipan berjumlah 30 orang lansia muda (young old) dengan rentang usia 60-74 tahun. Hasil penelitian ini menunjukkan lansia yang memiliki kualitas hidup tinggi $8(26,7 \%)$, sedang $16(53,3 \%)$, rendah $6(20 \%)$ Berdasarkan skor rerata tertinggi, lansia memiliki persepsi yang paling puas terhadap domain kualitas hidup kemandirian $(4,1778)$, domain spiritualitas $(3,8667)$ dan kesehatan fisik $(3,667)$. Kualitas hidup lansia yang tinggal di panti berkaitan dengan lamanya mereka tinggal. Hasil uji perbedaan data demografis hanya menunjukkan adanya perbedaan kualitas hidup berdasarkan lamanya partisipan tinggal di panti.
\end{abstract}

Kata Kunci: kualitas hidup, lansia, panti wreda.

\section{PENDAHULUAN \\ Latar Belakang}

Individu yang telah mencapai usia 60 tahun ke atas berdasarkan Undang-undang Republik Indonesia Nomor 13 Tahun 1998 dikategorikan sebagai lanjut usia (lansia). Pada negara maju maupun negara berkembang, komposisi penduduk lansia meningkat dengan pesat (Kementerian Kesehatan RI, 2017). Di Indonesia, persentase penduduk lansia meningkat sekitar dua kali lipat menjadi $8.97 \%$ atau 23,4 juta orang selama kurun waktu hampir lima dekade (1971-2017) (Badan Pusat Statistik, 2018). Jumlah penduduk lansia di Indonesia diprediksi akan terus 
mengalami peningkatan, yaitu $\pm 27,08$ juta pada tahun $2020, \pm 33,69$ juta pada tahun $2025, \pm 40,95$ juta pada tahun 2030 dan mencapai $\pm 48,19$ juta pada tahun 2035 (Kementerian Kesehatan RI, 2017). Peningkatan jumlah penduduk lansia antara lain disebabkan karena adanya penurunan tingkat infertilitas, penurunan angka kematian pada bayi, dan peningkatan jumlah lansia yang dapat bertahan hidup. Hal ini didukung oleh kesehatan penduduk yang meningkat karena adanya kemajuan dalam pendidikan, ekonomi, layanan kesehatan, asupan gizi dan masalah sanitasi yang semakin baik (UNFPA, 2012),

Setiap lansia akan mengalami penuaan atau aging yang merupakan proses kemunduran secara bertahap dalam berbagai aspek dan merupakan hal yang tidak dapat dihindari (Papalia, Olds \& Feldman, 2009). Sebagai lansia, individu berada pada tahap akhir perkembangan dengan berbagai perubahan pada aspek fisik, kognitif, dan psikososial (Papalia et al., 2009). Lansia yang mengalami perubahan dan menghadapi masalah terkait ketidakmampuan finansial, janda atau bercerai, tidak memiliki anak atau keluarga dekat dan memiliki masalah signifikan dalam melakukan aktivitas sehari-hari pada umumnya akan tinggal di panti wreda (Cavanaugh \& Blanchard-Fields, 2011). Hal ini karena masalah ekonomi dan tidak adanya dukungan keluarga dapat menyebabkan lansia menjadi terlantar sehingga akhirnya mereka harus masuk dan tinggal di panti wreda (Rekawati, Sahar, \& Abas, 2018).

Berdasarkan Kepmensos No. 50 tahun 2004, Panti Sosial Tresna Werdha (PSTW) adalah panti sosial yang mempunyai tugas memberikan bimbingan dan pelayanan bagi lanjut usia terlantar agar dapat hidup secara wajar dalam kehidupan masyarakat. Meskipun panti wreda merupakan sebuah tempat tinggal bagi lansia karena adanya ketidakberdayaan, namun beberapa lansia yang tinggal di panti wreda merasa kurang dihargai dan diberdayakan sehingga timbul perasaan terasing dan tidak berdaya (Rekawati et al., 2018). Terdapat pula pandangan bahwa panti wreda merupakan sebuah tempat yang aman, namun membuat lansia terbatas dalam melakukan kontak sosial serta merupakan tempat pembuangan bagi lansia karena tidak mendapatkan perawatan dari keluarga sendiri hingga nantinya meninggal (Yulitasari, Amatayakul \& Karuncharernpanit, 2015).

Pandangan dan persepsi lansia tersebut dapat menggambarkan kualitas kehidupan mereka, di mana menurut WHO (1996) kualitas hidup (quality of life) merupakan persepsi individu tentang posisinya dalam kehidupan sesuai dengan konteks budaya dan sistem nilai di lingkungan tempat tinggal terkait dengan tujuan, harapan standar, serta masalah mereka. Kualitas hidup merupakan sebuah konsep yang luas dan secara kompleks dipengaruhi oleh kesehatan fisik, kondisi psikologis, kepercayaan pribadi, hubungan sosial, serta hubungan dengan lingkungan (WHO, 1996). Diener dan Suh (1997) mengemukakan bahwa kualitas hidup dapat didasarkan atas pencapaian hal-hal yang diinginkan oleh individu karena kualitas hidup merupakan pengalaman individu itu sendiri. Saat individu merasa bahwa dalam hidup mereka memiliki pengalaman yang baik dan sesuai dengan keinginannya, dapat diasumsikan bahwa mereka mendapatkan perasaan senang dan damai serta kepuasan hidup. Hal ini didukung oleh penelitian yang dilakukan oleh Valikhani (2019) bahwa kualitas hidup berhubungan dengan stres dan kesehatan mental yang buruk. Berbagai kondisi negatif pada lansia seperti, terjatuh, tinggal di panti wreda, dan kematian dapat berpengaruh terhadap rendahnya kualitas hidup (Kojima, Iliffe, Jivraj, \& Walters, 2016). Berdasarkan penelitian yang dilakukan oleh Appulembang dan Dewi (2017), terdapat hubungan antara usia dengan kualitas hidup. Kualitas hidup yang baik diperlukan oleh lansia karena hal tersebut membuat mereka dapat beradaptasi dengan life stressor serta menjadi lebih kuat terhadap kondisi fisik yang rentan terhadap penyakit (Gurung, 2014). 
Pandangan lansia yang buruk mengenai panti wreda sejalan dengan penelitian yang telah dilakukan oleh Putri, Fitriana, Ningrum, dan Sulastri (2015). Penelitian yang dilakukan menggunakan alat ukur kualitas hidup dari WHO ini menunjukkan bahwa lansia yang tinggal di panti wreda Bandung sebagian besar memiliki kualitas hidup pada kategori kurang. Hal ini berbeda dengan hasil penelitian yang dilakukan oleh Pramesona dan Taneepanichskul (2018) pada lansia yang tinggal di panti wreda di Yogyakarta. Pada penelitian ini, dengan menggunakan alat ukur yang sama ditemukan bahwa sebagian besar lansia di panti wreda memiliki kualitas hidup dengan kategori baik. Berdasarkan perbedaan hasil penelitian tersebut, maka penelitian ini akan melihat kualitas hidup lansia yang ada di panti wreda.

Berdasarkan latar belakang masalah yang telah dipaparkan, terdapat perbedaan hasil penelitian mengenai kualitas hidup lansia yang tinggal di panti. Oleh karena itu, tujuan penelitian ini adalah menggambarkan kualitas hidup lansia yang tinggal di panti sosial tresna wreda $\mathrm{X}$.

\section{METODE PENELITIAN}

\section{Partisipan dan Prosedur Penelitian}

Partisipan dalam penelitian ini berjumlah 30 orang dengan kriteria a) Berusia 60-74 tahun (kategori young old), b) Tinggal di panti sosial tresna wreda X , c) Mampu beraktivitas secara mandiri, d) Dapat berkomunikasi. Panti wreda $X$ dipilih karena panti tersebut memberikan pelayanan dan fasilitas yang baik kepada lansia sehingga diharapkan dapat memberikan gambaran kondisi lingkungan yang setara dengan lansia yang ada di luar panti. Panti tersebut memiliki jumlah lansia yang memadai untuk menjadi partisipan sesuai kategori. Penelitian ini terdiri dari dua tahap. Tahap pertama adalah melakukan Diskusi Kelompok Terarah (FGD) dengan partisipan sebanyak 5 orang lansia untuk mengetahui gambaran umum kondisi lansia di panti. Pada tahap kedua, penelitian ini menggunakan metode kuantitatif dengan pemberian kuesioner yang dibacakan kepada partisipan. Data yang didapat diolah menggunakan SPSS dan dianalisa berdasarkan teori. Teknik pemilihan sampel pada penelitian adalah non-probability, yaitu purposive sampling (pengambilan sampel berdasarkan kriteria yang telah ditentukan).

\section{Instrumen Penelitian}

Variabel kualitas hidup dalam penelitian ini diukur dengan menggunakan alat ukur Kualitas Kehidupan Lansia. Alat ukur ini merupakan alat ukur kualitas hidup bagi lansia yang dibuat oleh Dewi, Rostiana dan Rumawas (2018) yang menggabungkan definisi kualitas hidup berdasarkan World Health Organization (WHO) dan Badan Kependudukan dan Keluarga Berencana Nasional (BKKBN) serta melibatkan nilai-nilai kearifan lokal dari kultur Indonesia. Karakteristik unik yang sesuai dengan kultur indonesia adalah kudu leren yang termasuk domain kesehatan fisik, diuwongke yang termasuk domain psikologis, berhemat yang termasuk domain kemandirian, rembugan dan musyawarah mufakat yang termasuk domain hubungan sosial, nrimo yang termasuk domain spiritual, dan tua namun tetap aktif yang termasuk domain pemberdayaan diri. Pemberdayaan diri merupakan domain tambahan yang ditambahkan pada alat ukur ini.

Alat ukur kualitas kehidupan lansia terdiri atas 7 domain, yaitu (1) lingkungan, contohnya "Seberapa bersih atau sehat lingkungan fisik di sekitar Anda?"; (2) kemandirian, contohnya "Sejauh mana Anda merasa dapat mengatur aktivitas Anda secara mandiri?"; (3) spiritual, contohnya "Sejauh mana keyakinan yang Anda miliki dapat memberikan kekuatan untuk menghadapi kesulitan?"; (4) hubungan sosial, contohnya "Seberapa puas hubungan pribadi Anda dengan orang lain?"; (5) pemberdayaan diri, contohnya "Sejauh mana Anda merasa dapat bermanfaat bagi orang lain?"; (6) kesehatan fisik, contohnya Sampai sejauh mana kondisi sakit 
(yang umum Anda rasakan), menghalangi Anda melakukan aktivitas sehari-hari?"; dan (7) kondisi psikologis, contohnya "Seberapa puas Anda menikmati hidup Anda?". Alat ukur ini terdiri atas 39 butir pernyataan dalam bentuk self-report dan menggunakan 5 skala likert. Pada penelitian yang dilakukan oleh Dewi et al. (2018), alat ukur ini memiliki Alpha Cronbach $=0.91$.

Setelah dilakukan uji validitas menggunakan SPSS terhadap alat ukur Kualitas Kehidupan Lansia, terdapat 4 butir yang gugur. Keempat butir tersebut terdiri dari 1 butir domain hubungan sosial dan 3 butir domain pemberdayaan diri. Hal ini karena butir tersebut mengenai hubungan dengan keluarga dan kegiatan sosial, sedangkan di warga binaan di panti sebagian besar sudah tidak memiliki keluarga dan tidak mengikuti kegiatan sosial. Nilai Alpha Cronbach pada penelitian ini adalah 0.894. Berdasarkan hasil uji normalitas dengan menggunakan KolmogovSmirnov, diketahui bahwa data yang diambil pada penelitian ini menggunakan kuesioner Kualitas Kehidupan Lansia terdistribusi normal dengan nilai $Z=0.732, p<0,05$.

\section{HASIL DAN PEMBAHASAN}

Hasil dari alat ukur kualitas kehidupan yang diberikan kepada partisipan untuk mengetahui kualitas kehidupan mereka didapat nilai mean empirik sebesar 3,5848 dan standar deviasi sebesar 0,48230. Berdasarkan hasil tersebut, maka kualitas hidup partisipan dapat dikategorikan menjadi tinggi, sedang dan rendah (Tabel 1). Sebagian besar lansia yang menjadi partisipan $(53,3 \%)$ memiliki kualitas hidup pada tingkat sedang dan hanya $20 \%$ lansia memiliki kualitas hidup yang masih rendah.

Tabel 1. Kategorisasi Kualitas Kehidupan Partisipan

\begin{tabular}{ccc}
\hline Kategori & Frekuensi & Prosentase \\
\hline Rendah & 6 & 20 \\
Sedang & 16 & 53,3 \\
Tinggi & 8 & 26,7 \\
\hline
\end{tabular}

Berdasarkan seluruh domain kualitas hidup lansia, didapatkan nilai mean empirik yang berbedabeda pada. Domain dengan mean tertinggi adalah domain kemandirian, spiritual, dan kesehatan fisik.

Tabel 2. Skor Rerata Domain Kualitas Kehidupan Partisipan

\begin{tabular}{ccc}
\hline Domain & Rerata & Standar Deviasi \\
\hline Kemandirian & 4,1778 & 0,98934 \\
Spiritual & 3,8667 & 0,80337 \\
Kesehatan fisik & 3,6667 & 0,69205 \\
Psikologis & 3,5238 & 0,65124 \\
Pemberdayaan diri & 3,4778 & 0,91678 \\
Lingkungan & 3,4722 & 0,62220 \\
Hubungan Sosial & 3,0917 & 0,47563 \\
\hline
\end{tabular}

Pada tabel 3. dipaparkan mengenai karakteristik sosiodemografi partisipan yang berpartisipasi dalam penelitian ini, yaitu 30 orang lansia dengan rata-rata berusia 67 tahun dengan komposisi jumlah lansia wanita lebih banyak (70\%) dibandingkan jumlah lansia pria (30\%). Sebagian besar dari partisipan memiliki pendidikan yang rendah, yaitu tingkat SD $(46,7 \%)$ dan bahkan tidak bersekolah $(23,3 \%)$. Sebagian besar kondisi fisik partisipan masih baik dengan hanya sebagian kecil partisipan $(20 \%)$ yang memiliki $\geq 2$ jenis penyakit kronis. Penyakit kronis yang dimiliki oleh partisipan contohnya adalah hipertensi dan diabetes. Sebanyak 36,7\% partisipan merupakan warga binaan yang baru di dalam lingkungan panti dan sebagian besar partisipan $(73,3 \%)$ tinggal di panti karena terpaksa, seperti tidak adanya tempat tinggal dan mereka dibawa oleh petugas 
'Satpol PP', tidak ada lagi keluarga yang mengurus dan faktor kesulitan ekonomi sehingga mereka dirujuk oleh teman atau tetangga untuk tinggal di panti.

Berdasarkan hasil uji beda kualitas hidup berdasarkan karakteristik demografinya, hanya terdapat perbedaan kualitas hidup berdasarkan lamanya tinggal di panti dengan $\mathrm{F}=3,505 ; \mathrm{p}=0,044<$ 0,05. Partisipan dengan kualitas hidup rendah lebih banyak memiliki yang masa tinggal $\leq 1$ tahun dibandingkan yang memiliki masa tinggal selama 1-3 tahun $(33,3 \%)$ dan $>3$ tahun $(0 \%)$. Kualitas hidup sedang lebih banyak dimiliki oleh partisipan dengan masa tinggal 1-3 tahun $(37,5 \%)$ dan $>3$ tahun $(37,5 \%)$. Sedangkan kualitas hidup yang tinggi lebih banyak dimiliki oleh partisipan dengan masa tinggal $>3$ tahun $(62,5 \%)$ dibandingkan partisipan yang tinggal selama $\leq$ 1 tahun $(37,5 \%)$.

Tabel 3. Karakteristik Sosiodemografik Partisipan

\begin{tabular}{|c|c|c|c|c|}
\hline \multirow[b]{2}{*}{ Karakteristik } & \multirow[b]{2}{*}{$\begin{array}{c}\text { Seluruh } \\
\text { partisipan } \\
\text { f }(\%)\end{array}$} & \multicolumn{3}{|c|}{ Quality of life } \\
\hline & & $\begin{array}{c}\text { Rendah } \\
\text { f (\%) }\end{array}$ & $\begin{array}{c}\text { Sedang } \\
\text { f }(\%)\end{array}$ & $\begin{array}{l}\text { Tinggi } \\
\text { f (\%) }\end{array}$ \\
\hline \multicolumn{5}{|l|}{ Jenis kelamin } \\
\hline Laki-laki & $9(30)$ & $1(11,2)$ & $4(44,4)$ & $4(44,4 \%)$ \\
\hline Perempuan & $21(70)$ & $5(23,8)$ & $12(57,2 \%)$ & $4(19 \%)$ \\
\hline \multicolumn{5}{|l|}{ Usia (tahun) } \\
\hline $60-64$ & $12(40)$ & $3(25)$ & $5(41,7 \%)$ & $4(33,3 \%)$ \\
\hline $65-69$ & $6(20)$ & $1(16,7)$ & $4(66,6 \%)$ & $1(16,7 \%)$ \\
\hline $70-74$ & $12(40)$ & $2(16.7)$ & $7(58,3 \%)$ & $2(25 \%)$ \\
\hline \multicolumn{5}{|l|}{ Status pernikahan } \\
\hline Menikah & $27(90)$ & $5(18,5)$ & $16(59,3 \%)$ & $6(22,2 \%)$ \\
\hline Tidak Menikah & $3(10)$ & $1(33,3)$ & $0(0 \%)$ & $2(66,7 \%)$ \\
\hline \multicolumn{5}{|l|}{ Tingkat pendidikan } \\
\hline Tidak sekolah & $7(23,3)$ & $3(42,9)$ & $4(57,1 \%)$ & $0(0 \%)$ \\
\hline $\mathrm{SD}$ & $14(46,7)$ & $2(15,3)$ & $6(42,9 \%)$ & $6(42,9 \%)$ \\
\hline SMP & $4(13,3)$ & $0(0)$ & $3(75 \%)$ & $1(25 \%)$ \\
\hline SMA & $4(13,3)$ & $1(25)$ & $2(50 \%)$ & $1(25 \%)$ \\
\hline Perguruan tinggi & $1(3,3)$ & 0 & $1(100 \%)$ & $0(0 \%)$ \\
\hline \multicolumn{5}{|l|}{ Penyakit kronis (tahun) } \\
\hline$\leq 1$ & $24(80)$ & $4(16,7)$ & $12(50 \%)$ & $8(33,3 \%)$ \\
\hline$\geq 2$ & $6(20)$ & $2(33,3)$ & $4(66,7 \%)$ & $0(0 \%)$ \\
\hline \multicolumn{5}{|l|}{ Alasan tinggal di panti } \\
\hline Kemauan sendiri & $8(26,7)$ & 0 & $5(62,5 \%)$ & $3(37,5 \%)$ \\
\hline Terpaksa & $22(73,3)$ & $6(27,3)$ & $11(50 \%)$ & $5(22,7 \%)$ \\
\hline \multicolumn{5}{|l|}{ Lamanya di panti (tahun )* } \\
\hline$\leq 1$ & $11(36,7)$ & $4(66,7)$ & $4(25 \%)$ & $3(37,5 \%)$ \\
\hline $1-3$ & $8(26,6)$ & $2(33,3)$ & $6(37,5 \%)$ & $0(0 \%)$ \\
\hline$>3$ & $11(36,7)$ & 0 & $6(37,5 \%)$ & $5(62,5 \%)$ \\
\hline${ }^{*} \mathrm{~F}=3,505 ; \mathrm{p}=0,044<0$ & & & & \\
\hline
\end{tabular}

Berdasarkan hasil penelitian, sebagian besar lansia yang tinggal di panti wreda memiliki kualitas hidup pada tingkat sedang. Hal ini sesuai dengan penelitian sebelumnya yang dilakukan oleh Pramesona dan Taneepanichskul (2018) bahwa kualitas hidup lansia di panti wreda sebagian besar berada pada kategori sedang. Kualitas hidup lansia pada penelitian ini berada pada kategori baik dapat dikaitkan karena kondisi fisik partisipan masih baik. Meta analisis yang dilakukan oleh Crocker et al.(2019) menunjukkan terdapat hubungan yang jelas dan kuat antara kerentanan pada lansia dengan kualitas hidup yang lebih rendah. Kondisi fisik lansia yang dengan 2 atau lebih penyakit kronis secara signifikan mengalami penurunan kualitas hidup terkait kesehatan 
karena mengalami kendala pada kesehatan secara umum, fungsi tubuh, kemampuan perawatan diri, dan adaptasi emosi serta sosial (Gu et al., 2018). Pada penelitian ini partisipan dengan 2 atau lebih penyakit kronis memiliki kualitas hidup rendah $(33,3 \%)$, sedang $(66,7 \%)$, dan tinggi $(0 \%)$.

Kemandirian merupakan domain kualitas kehidupan dengan rerata yang paling tinggi (rerata $=$ 4,1778; SD = 0,98934). Kapasitas fungsional (fungsi fisik) merupakan variabel prediktif yang signifikan terhadap otonomi atau kemandirian dalam instrumental kegiatan kehidupan sehari-hari (Tornero-Quiñones, Sáez-Padilla, Díaz, Robles, \& Robles, 2020). Kemandirian lansia di dalam panti dapat meningkatkan kepuasan lansia dan meningkatkan aktivitas menyenangkan sehingga dapat meningkatkan kualitas hidup mereka (Welford, Murphy, Rodgers \& Frauenlob, 2012). Menurut WHO (2012), kemandirian merupakan domain yang meliputi mobilitas, aktivitas sehari-hari, ketergantungan pada obat-obatan medis, kapasitas komunikasi, dan kapasitas bekerja atau melakukan aktivitas.

Spiritualitas merupakan domain dengan rerata tertinggi kedua pada penelitian ini (rerata = 3,8667; SD = 0,80337). Oleh karena itu, dapat diindikasikan bahwa spiritualitas memiliki peran yang cukup besar pada kualitas hidup lansia di penelitian ini. Hal ini sejalan dengan hasil FGD, bahwa lansia di panti merasa senang dengan kegiatan keagamaan yang diadakan oleh panti karena dengan demikian mereka dapat melaksanakan kegiatan ibadah dengan lebih teratur. Hal ini juga didukung bahwa intervensi keagamaan secara berkelompok dapat meningkatkan kualitas hidup pada lansia (Pramesona \&Taneepanichskul, 2018).

Domain sosial menjadi domain dengan rerata terendah (rerata $=3,0917 ; \mathrm{SD}=0,47563$ ). Hal ini sangat dimungkinkan karena lansia yang tinggal di PSTW dalam penelitian ini kebanyakan merupakan lansia yang sudah tidak memiliki keluarga atau tidak berhubungan lagi dengan keluarganya. Berdasarkan penelitian yang dilakukan oleh Rahayu, Daulima, dan Putri (2018) bahwa keluarga yang mengunjungi lansia dan memberikan dukungan emosional dapat membuat mereka bahagia dan melanjutkan kehidupan mereka di panti dengan baik. Selain itu, berdasarkan hasil FGD juga didapatkan bahwa kondisi fisik sebagian besar lansia di panti yang sudah kurang baik, seperti sulit berjalan membuat partisipan tidak dapat melakukan berinteraksi satu sama lain.

Berdasarkan data demografi, ada perbedaan kualitas hidup ditinjau dari lamanya lansia tinggal di panti. Semakin lama tinggal di panti (> 3 tahun), ditemukan tidak ada lansia dengan kualitas hidup yang rendah. Hal ini dapat dimungkinkan karena pengalaman waktu lansia bertransisi ke panti wreda dapat menimbulkan stres karena adanya perasaan kehilangan, baik kehilangan lingkungan, rumah, maupun waktu bebas mereka bersama teman atau orang lain yang ada di sekitar mereka sebelumnya (Sury et al. dalam Müller, Lautenschläger, Meyer, \& Stephan, 2017). Stres yang dialami oleh lansia selama masa transisi dapat berkaitan dengan kualitas hidup (Valikhani, 2019). Pada saat FGD, lansia yang sudah lebih lama, memiliki pengalaman bahwa lansia dapat lebih menikmati berbagai hal yang ada di panti. Para lansia dapat merasa lebih nrimo jika memang harus berada di panti. Nrimo (menerima keadaan dirinya, situasi, dan hubungan sosial dengan lingkungan sekitar dengan ikhlas), merupakan value atau kearifan lokal, sebagai karakteristik unik masyarakat Jawa yang termasuk domain kualitas hidup spiritual (Dewi et al., 2018). Lansia juga sudah mengenal perawat dan petugas yang menyenangkan serta memberikan perawatan yang baik sehingga mereka merasa dihargai. Hal ini sesuai dengan kearifan lokal masyarakat Jawa, yaitu diuwongke yang artinya dihargai sebagai pribadi, dalam hal ini sebagai orang tua, bukan sebagai obyek dalam interaksi sosial (Dewi et al., 2018). 
Keterbatasan dalam penelitian ini adalah latar belakang beberapa partisipan berasal dari status sosial ekonomi yang kurang baik, seperti tidak bersekolah atau berpendidikan rendah. Hal ini cukup membuat partisipan kesulitan atau kurang memahami kalimat atau pernyataan yang ada di dalam kuesioner. Partisipan yang bertanya maksud pernyataan kuesioner diberikan penjelasan tambahan mengenai butir pertanyaan tersebut sehingga dapat mempengaruhi jawaban yang diberikan. Kondisi fisik partisipan yang sudah berusia lanjut, juga membuat partisipan kurang berkonsentrasi saat diberikan pertanyaan sehingga penelitian selanjutnya diharapkan dapat membagi sesi dengan menyesuaikan kondisi fisik dan suasana hati partisipan.

\section{KESIMPULAN DAN SARAN}

Berdasarkan penelitian yang dilakukan terhadap 30 orang lansia yang tinggal di panti sosial tresna werdha, dapat disimpulkan bahwa sebagian besar lansia memiliki kualitas hidup pada tingkat sedang. Hanya sebagian kecil lansia pada penelitian ini yang memiliki kualitas hidup rendah. Berdasarkan rerata skor yang diperoleh dari kuesioner kualitas hidup, persepsi lansia mengenai kepuasan pada domain kualitas hidup kemandirian, spiritualitas, dan kesehatan fisik merupakan yang tertinggi. Kualitas hidup lansia yang tinggal di panti berkaitan dengan lamanya mereka tinggal. Semakin lama mereka tinggal di panti, ditemukan lebih banyak lansia dengan kualitas hidup yang baik. Berdasarkan kesimpulan di atas, saran-saran dapat diberikan baik untuk a) warga binaan yang tinggal di panti wreda dan b) panti dan tenaga kesehatan.

Pertama, saran bagi lansia yang tinggal di panti adalah oleh karena sangat sedikit dukungan dari keluarga, diharapkan lansia dapat menjalin hubungan interpersonal yang lebih baik dengan sesama warga binaan yang lain. Lansia juga dapat lebih aktif untuk mengikuti kegiatan yang diadakan oleh pihak panti, seperti kegiatan senam dan panggung gembira untuk dapat melakukan interaksi sosial baik dengan sesama warga binaan maupun dengan petugas panti. Selain itu, diharapkan lansia tetap dapat aktif mengikuti kegiatan keagamaan yang diadakan oleh pihak panti.

Kedua, saran bagi pihak panti kiranya pihak panti dapat menambah kegiatan bagi lansia yang dilakukan secara berkelompok, seperti kegiatan seni atau hidroponik sehingga melalui kegiatan tersebut diharapkan lansia dapat lebih berinteraksi dengan sesama warga binaan yang saling dan saling mendapatkan dukungan sosial. Selain itu, kiranya pihak panti dapat meningkatkan kerja sama dengan tenaga medis atau memberikan kegiatan yang berfokus untuk menjaga kondisi fisik lansia yang tinggal di panti sehingga kiranya kualitas hidup lansia yang tinggal di sana dapat tetap terjaga dengan baik.

\section{Ucapan Terima Kasih}

Peneliti mengucapkan terimakasih kepada seluruh partisipan yang berkenan untuk terlibat dalam penelitian ini. Selain itu, peneliti juga mengucapkan terima kasih kepada panti sosial tresna wreda yang telah bersedia memfasilitasi penelitian ini.

\section{REFERENSI}

Appulembang, Y. A., \& Dewi, F. I. R. (2017). Pengembangan Alat Ukur Quality of Life Urban Community. Jurnal Muara Ilmu Sosial, Humaniora, dan Seni, 1 (1), 272-277.

Badan Pusat Statistik. (2018). Statistik Penduduk Lanjut Usia 2017. https://www.bps.go.id/publication/2018/04/13/7a130a22aa29cc8219c5d153/statistikpenduduk-lanjut-usia-2017.html

Cavanaugh, J. C., \& Blanchard-Fields, F. (2011). Adult Development and Aging ( $7^{\text {th }}$ ed.). United Australia: Cengage Learning. 
Crocker, T. F., Brown, L., Clegg, A., Farley, K., Franklin, M., Simpkins, S., \& Young, J. (2019). Quality of life is substantially worse for community-dwelling older people living with frailty: systematic review and meta-analysis. Quality of Life Research, 28, 2041-2056. doi: https://doi.org/10.1007/s11136-019-02149-1

Dewi, F.I.R., Rostiana, \& Rumawas, M. E. (2018). The Assessment Model of Quality of Life in Indonesian Elderly. Advanced Science Letters, 24 (1), 417-419. doi: https://doi.org/10.1166/asl.2018.12026

Diener E \& Suh, E. (1997). Measuring Quality of Life: Economic, Social, and Subjective Indicators. Social Indicators Research, 40. 189-216.

Gu, J., Chao, J., Chen, W., Xu, H., Zhang, R., He, T., \& Deng, L. (2018). Multimorbidity and health-related quality of life among the community-dwelling elderly: A longitudinal study. Archives of Gerontology and Geriatrics, 74, 133-140. doi:10.1016/j.archger.2017.10.019

Gurung, R. A. R. (2014). Health Psychology: A Cultural Approach (3 ${ }^{\text {th }}$ ed.). United States of America, USA: Cengage Learning.

Kementrian Kesehatan R.I. (2017). Analisis lansia di indonesia. (Publication No. P1). Jakarta, INA: Pusat Data dan Informasi. https://pusdatin.kemkes.go.id/article/view/18012600001/analisis-lansia-di-indonesia2017.html

Kojima, G., Iliffe, S., Jivraj, S., \& Walters, K. (2016). Association between Frailty and Quality of Life among Community-Dwelling Older People: A Systematic Review and MetaAnalysis. Journal of Epidemiology \& Community Health, 70 (7), 716-721. doi: 10.1136/jech-2015-206717

Müller, C., Lautenschläger, S., Meyer, G., \& Stephan, A. (2017). Interventions to Support People with Dementia and Their Caregivers During the Transition from Home Care to Nursing Home Care: A Systematic Review. International Journal of Nursing Studies, 71, 139152. doi: https://doi.org/10.1016/j.ijnurstu.2017.03.013

Papalia, D. E., Wendkos-Olds, S., \& Duskin-Feldman, R. (2009). Human development $\left(11^{\text {th }}\right.$ ed.). New York, NY: McGraw-Hill.

Pramesona, B. A., \& Taneepanichskul, S. (2018). Factors Influencing the Quality of Life among Indonesian Elderly: A Nursing Home-Based Cross-Sectional Survey. Journal of Health Research, 32(5), 326-333. doi: https://doi.org/10.1108/JHR-08-2018-037

Putri, S. T., Fitriana, L. A., Ningrum, A., \& Sulastri, A. (2015). Studi Komparatif: Kualitas Hidup Lansia yang Tinggal Bersama Keluarga dan Panti. Jurnal Pendidikan Keperawatan Indonesia, 1 (1), 1-6.

Rahayu, S., Daulima, N. H. C., \& Putri, Y. S. E. (2018). The Experience of Older People Living in An Elderly Residential Home (Panti Sosial Tresna Werdha): A Phenomenology. Enfermería Clínica, 28 (1), 79-82. doi: https://doi.org/10.1016/S1130-8621(18)30042-1

Rekawati, E., Sahar, J., \& Abas, I. (2018). The Experience of Older People Living in Nursing Home (Panti Wredha) in DKI Jakarta, Indonesia. Enfermería Clínica, 28 (1), 347-352. doi: https://doi.org/10.1016/S1130-8621(18)30183-9

Tornero-Quiñones, I., Sáez-Padilla, J., Espina Díaz, A., Abad Robles, M. T., \& Sierra Robles, Á. (2020). Functional ability, frailty and risk of falls in the elderly: relations with autonomy in daily living. International journal of environmental research and public health, 17(3), 1006. doi: https://doi.org/10.3390/ijerph17031006

United Nations Population Fund (UNFPA). (2012). Ageing in the twenty-first century: A celebration and a challenge. https://www.unfpa.org/publications/ageing-twenty-firstcentury 
Valikhani, A., Ahmadnia, F., Karimi, A., \& Mills, P. J. (2019). The Relationship between Dispositional Gratitude and Quality of Life: The Mediating Role of Perceived Stress and Mental Health. Personality and Individual Differences, 141, 40-46. doi: https://doi.org/10.1016/j.paid.2018.12.014

Welford, C., Murphy, K., Rodgers, V., \& Frauenlob, T. (2012). Autonomy for older people in residential care: A selective literature review. International Journal of Older People Nursing, 7(1), 65-69. doi: https://doi.org/10.1111/j.1748-3743.2012.00311.x

World Health Organization. (1996). WHOQOL-BREF: introduction, administration, scoring and generic version of the assessment: field trial version, December 1996. https://apps.who.int/iris/handle/10665/63529

World Health Organization. (2012). Programme on mental health: WHOQOL user manual, revision 2012. World Health Organization. https://apps.who.int/iris/handle/10665/77932

Yulitasari, B. I., Amatayakul, A., \& Karuncharerernpanit, S. (2015). Factors Affecting Stress in Elderly Staying in Public Nursing Home in Yogyakarta, Indonesia [Proceeding]. 3rd AASIC: Sustainable Development of Asian Community, Bangkok. http://aasic.org/proc/aasic/article/view/249 